\title{
Kutai Kartanegara District Local Government Supervision On Prosperous Rice Distribution In Muara Wis 2016
}

\author{
Akbar Prabawa \\ Department of Government Science Padjadjaran University, \\ Bandung, Indonesia \\ Nandang Alamsah Deliarnoor \\ Department of Government Science Padjadjaran University, \\ Bandung, Indonesia \\ Agustinus Widanarto \\ Department of Government Science Padjadjaran University, \\ Bandung, Indonesia
}

\begin{abstract}
Supervision is one of the basic management functions that is carried out so that group activities in implementing program performance are in accordance with the predetermined plans, including prosperous rice distribution in Muara Wis. Kutai Kartanegara District Local Government is required to be able to supervise the distribution of prosperous rice which is oriented towards the established standards, namely the right target, right price, right quality, right amount, on time, and right administration. This research focuses on the supervision process carried out by the Kutai Kartanegara District Local Government in distributing prosperous rice in Muara Wis. The results of the research found that Kutai Kartanegara District Local Government until now has not been able to optimize the supervising process of the distribution of prosperous rice in Muara Wis. This indicated that the existence of prosperous rice assistance that is not right on target for the people who need it because of the updated data. Moreover, the sense of the rice quality given for the community is very inappropriate, this happens at the stage of slow rice distribution to the community.
\end{abstract}

Keyword: Supervision, Local Government, Prosperous Rice

\section{INTRODUCTION}

Supervision is an important performance management, which being carried out so that the objectives in an organization in the management process implemented properly. Winardi (2008: 585) stated that supervision is an activity carried out by managers to ensure performance results in accordance with the results planned initially can be said that supervision is carried out so that the actors when implementing organizational program activities can carry out their performance in accordance with the organization's initial planning which is expected to minimize perversion, so Sarundjangan (2006: 240) argued that supervision helps in realizing three important things, such as in order to improve organizational performance by providing assessments and providing corrections if there are deviations, further Soewartojo (1995: 130) stated that supervision is not only oriented towards finding fault errors but provide advice, assessment if the performance carried out has deviated from the original plan whether intentional or not so that organizational performance can be improved. 
Likewise the government as a public organization needs to implement one form of supervision so that policy implementers from government programs can run according to the plan to achieve the objectives of policy decisions that have been made. This is based on the assumption that the government as a public institution cannot be separated from deviations government functions are clear as stated by Kaho (1995: 143) that the purpose of government supervision is to maintain and maintain the performance of government officials in providing services to the community in accordance with predetermined standard criteria.

One of the implemented government programs as a manifestation of the function of government services in the welfare sector is the Raskin (Rice for the poor) distribution in supporting community food security. According to FAO (Food and Agricultural Organization), food security is a situation where all people have sufficient amounts of safe and nutritious food for a healthy and active life at all times. (Budi Winarno, 2011: 187) Food security is very important so that Indonesian people can survive, which if there's issue arise such socioeconomic crises and even politics in Indonesia, increasingly high of rice price during the 1997/1998 economic crisis, which developed into a multidimensional crisis, triggering insecurity social conditions which endanger national economic stability and stability.

Therefore, it is very important to supervis the government performance in supporting the success of the Raskin distribution program so that the rice availability for the poor is fulfilled as a form of food security, especially for areas that are crisis to poverty. One of the crisis areas is Kutai Kartanegara District with one of its sub-districts, Muara Wis, so that the distribution of Raskin is important for the government in providing food for the people in Muara Wis with seven villages, Muara Wis Village, Sebemban Village, Lebak Mantan Village, Lebak Cilang Village, Melintang Village, Muara Engisap Village and Eng Sink Village, therefore it is necessary to supervis the government performance so that the distribution of Raskin can be channeled properly in accordance with the predetermined plan itself. The problem in distributing Raskin is not only locally but also nationally, where the mechanism for delivering Raskin is still a problem, prompting the central government to immediately rectify it. ${ }^{1}$

The East Kalimantan Food and Counseling Agency (BKPP) reminded the district and city governments in East Kalimantan regarding the obligation to conduct food supervision in ensuring consumer health and safety. The obligation was mandated by Government Regulation Number 41 Year 2007 concerning Local Organizations Organizations Against the Restructuring of Local Device Organizations. Based on these regulations, supervision and food security are a priority. So that it must be implemented by each region both provincial and district/city. ${ }^{2}$

Kutai Kartanegara District Local Government as guarantor of food security in its jurisdiction needs to supervise performance so that the Raskin distribution program is in accordance with the predetermined plans. The general guidelines for prosperous rice subsidies from Kutai Kartanegara District are published by the Deputy of Poverty and Social Protection Coordination Division No. B-247/D-II/KPS.01.00/02/2017, and technical guidelines for implementing the prosperous rice program have been established. through the Letter of the Kutai Kartanegara District Number 5/SE-BUP/HK/2017 dated May 22, 2017 concerning the

\footnotetext{
1 jokowi-target-perbaikan-program-raskin-2016 dari: https://www.cnnindonesia.com/nasional/20150622160647-32-61631/, accessed in 20 september 2016, 21.00 PM).

2 bkpp-kaltim-ingatkan-tentang-kewajiban-pengawasanpangandari: http://www.antarakaltim.com/berita/4872/ , accessed in 20 september 2016, 22.00 PM).
} 
implementation of the prosperous rice program, it was planned from Kutai Kartanegara District Local Government in the implementation of Raskin distribution in the district.

The plan contained the objectives to be achieved, namely the process of distributing rice to the poor or RTSMP (Recipient Target Households) of Kutai Kartanegara District, namely the right target, right time, right price, right quality, right administration, exact amount. Through these five targets, the government has set clear targets on the implementation of the Raskin distribution program, which is the basis of supervision carried out by Kutai Kartanegara District Local Government in overseeing the performance of government officials in carrying out raskin distribution.

The supervision carried out by Kutai Kartanegara District Local Government is considered still not implemented properly in supporting the achievement of the five targets above. The prosperous rice program that should be channeled to poor families was enjoyed by other communities. Many of these targets were caused by officers' negligence in the field and instead shared the prosperous rice with close relatives. One example that is in the Muara Wis subdistrict is precisely the low-lying village of the ex-community which was previously classified as poor and now has a decent life and still gets the assistance of prosperous rice.

According to G.R. Terry (1960) in carrying out the supervision process it is necessary to pay attention to the four important dimensions in the supervision mechanism illustrated below:

Figure 1.

\section{Supervision Dimension}

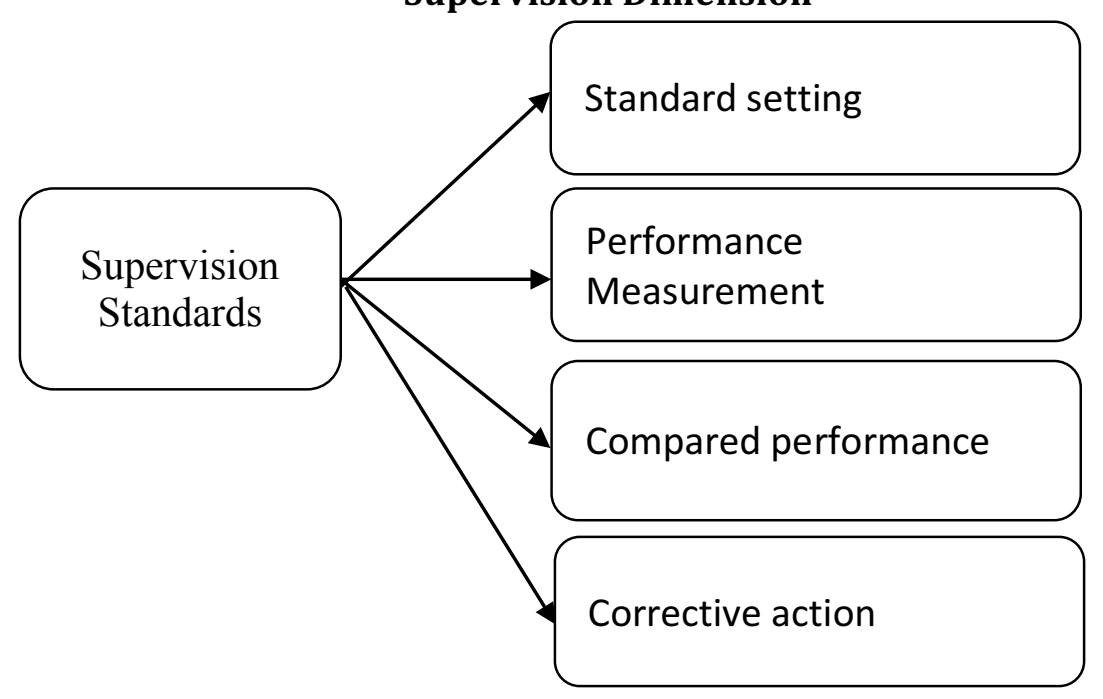

Starting with the existence of supervision standards. Determining standards or, as a basis for supervision (determining the standard or base for control) is one of the determinants of the achievement of clear rules in supervision to fit the main functions and tasks. Determining standards is not an easy matter but requires definite behavior related to motivational factors. Siagian (1995: 28) with definite behavior related to motivational factors. Indrawijaya (2000: 122 ) says that there is a high degree of closeness between supervision and individual and group behavior. In government organizations, the regulation of supervisory standards cannot be separated from the management function. This is because if there is an imbalance of supervision standards, it will cause a gap or disruption of the synchronization of organizational goals. Performance measurement from each result of supervision of Rastra distribution is needed to see whether the supervision standard is in accordance with the purpose of supervision. 
Measuring the performance or the measurement of performance on the results of work is done to look at various developments in activities, so that the final results of an activity can be known. Moreover, to compare the results of work with standards to ensure differences (Comparing performance with the standard and ascertainment of the difference if any). If the standard and performance measurements, then the supervising function is implemented to determine the evaluation by comparing the results of work and assessing the results, to determine sanctions if not in accordance with the standards and the preparation of predetermined distribution.

Corrective actions against irregularities that are not desired and determine remedial actions in accordance with established standards (Corecting deviating by means of remedial action). Supervision is part of an effort to determine a corrective action if intentional or unintentional deviations are found. The aim is to determine improvement efforts to be in line with the planned outcomes, so that the development implemented in accordance with the standard rules and performance achievements that have been determined, which ultimately, the benefits of the distribution of prosperous rice can certainly be felt by the community.

From the description above, can be seen that the supervision on prosperous rice distribution is related to four elements of supervision, namely supervision standards, measuring performance results, comparing work results, and corrective actions. Supervision of distribution of prosperous rice begins when the standards regarding activities to be carried out have been determined by management. This standard is then used as the basis for conducting assessments of the implemented activities. Measuring the results of work related to performance, the method that will be used to measure the activities carried out provides an assessment.

\section{RESEARCH METHOD}

Research method applied in this research is descriptive method with a qualitative approach because there will be examination on how the Kutai Kartanegara District Government supervises the prosperous rice distribution in Muara Wis. According to Creswell (2018: 4-6) qualitative research serves to understand the social problems of the community through the form of interviews and data collection from individuals involved in the social sector. Data conducted through interviews with several related parties and make field observations in collecting the required data. The function of the theoretical or descriptive method definition is used as material or reason to take the method of research conducted.

The Data used in this research is primary data sourced from the results of the discussion in the field about the supervision process and used secondary data derived from government documents concerning the supervision of prosperous rice. The technique of determining the informant by the researcher was purposive sampling, namely from the government at the district as the beneficiary communities of the welfare rice in the estuary of the Muara Wis.

\section{RESEARCH RESULTS AND DISCUSSION Determination of Standards in Prosperous Rice Distribution in Kutai Kartanegara District}

The Kutai Kartanegara District Government has made an initial plan as a supervision standard to be run by the government, the initial standard as stated by T. Hani Handoko (1984: 363365 ) is a benchmark in assessing the performance results of the Kutai Kartanegara District Local Government which is the target of achievement, targets or quotas that have been prepared in advance. The target, quota and achievement target set by Kutai Kartanegara District Local Government regarding the implementation of supervision is the general 
guideline for prosperous rice subsidies. Based on the Decree of the Kutai Kartanegara District Number: 151/SK-BUP/HK/2017 concerning the Establishment of the Prosperous Rice Subsidy Coordination Team for low-income communities in Kutai Kartanegara District, the targets, achievements and targets to be achieved by the government below:

1. Right on target, namely in terms of distributing raskin by Kutai Kartanegara District Local Government in accordance with the RTSPM data in the District area itself, which means reaching the recipients who need it.

2. Timely namely the government in distributing according to the time specified in the general guidelines for raskin distribution.

3. Exactly the number of target recipients or RTSPM get a share of the amount determined by the government in accordance with the general guidelines for distribution of $15 \mathrm{~kg}$ per family.

4. Exact administration, namely data on the number of Raskin recipients (RTSPM) in accordance with the field, which means there is no difference between the data held by the government and the number of poor people in the field.

5. The right quality is the quality of good raskin so that it is suitable for consumption for RTSPM in Kutai Kartanegara District.

6. Exact price, namely the price charged to the community can be affordable according to the economic capacity of the poor.

Based on the objectives formulated by the government as a benchmark for supervising Raskin distribution, it can be seen that the determination of achievement with six indicators is more specific because if the targets are too general then what happens is obscurity and this complicates the supervision process (Wankel and Stoner quoted from Siswanto, 2005: 147). This certainly makes it easier for supervisory actors to provide assessments in the implementation of Raskin distribution programs in Kutai Kartanegara District. Based on the six indicators above, the supervisor can assess whether the distributor of Raskin rice in Muara Wis has achieved the target based on six indicators in realizing the success of the Raskin distribution program in the community. In line with Mc's opinion, Farland cited by Suwarno (1980: 143) that the supervision of an action is implemented by the leadership in order to find out the results of the implementation of the program. In this case, the supervision carried out by the supervisory apparatus from the Rastra implementing team at the Muara Wis was an attempt to find out whether the distribution of raskin in all Muara Wiss by the channeling parties was in accordance with the six indicators above.

\section{The Kutai Kartanegara District Local Government Supervision Performance of Rastra Distribution of in Muara Wis}

The supervisor of Raskin distribution by the government was carried out by a team consisting of one chairperson and one secretary. The team carried out supervision by checking and going around each village during the distribution of Raskin rice. The supervisory team capitalized on data from the Raskin recipient or commonly abbreviated (RTSPM) in Muara Wis to ascertain whether the rice sent was in accordance with the data received or not. Performance measurement based on measuring instruments (recipient raskin data), in accordance with the opinion of Robbins and Mary (2005: 171) who stated that in terms of supervising the distribution of Raskin the measure is the report on the number of recipients of rice raskin so that the data can see whether rice has been channeled according to the initial standard setting which is right on target for the recipient (RTSPM).

The fact is that in carrying out the supervision the supervisor team did not jump directly at the lower sub-district level because the distributor had reported their performance to the village which would later be submitted to the supervisory team from the sub-district. This means that 
the supervision implemented is more of a supervisory feedback, where supervision is carried out after measuring the results of the performance that has been done. Or it can be said that the form of supervision other than being feedback is also a repressive supervision, where supervision is carried out after the activity is carried out and is intended to ensure that performance can be adjusted to the original plan, supervision is carried out by a comparative system that compares reports received and compares plans decided. So it can be concluded that the Rasta supervisory team made a comparison of reports from the village on the performance of the lower sub-district level in conducting Raskin distribution with the achievement of six indicators namely right on time, on time, on the right price, on the right quality and on administration.

\section{Comparison of Kutai Kartanegara District Local Government Supervision Performance of Rastra Distribution in Muara Wis}

Performance comparison is a form of comparison between the implementation in the field with the standards set. At this stage the Rasta supervisory team runs a comparative system that compares the performance of Raskin distribution in seven villages with standard $6 \mathrm{~T}$. The process requires a special level of analysis, if there is a deviation then the supervisor team can further interpret why the standard of $6 \mathrm{~T}$ is not achieved. Performance comparison can use a comparative system as explained by Suwarno Handayaningrat (1980: 144-146), namely:

1. Comparing reports on the results of implementation of work with plans that have been previously decided.

2. Conduct an analysis of these differences, including environmental factors that influence them.

3. Provide an assessment of the results of the implementation of work, including those responsible.

4. Making a decision or improvement effort or improvement

Based on the above method, it can be explained further about the results of the performance comparison that has been carried out by the Raskin rice distribution team in the entire Muara Wis, namely:

\section{Right Target}

The accuracy of the target in the implementation of the prosperous rice distribution assistance in 2016 in Muara Wis was 20\%, with the distribution being not given to targeted households beneficiaries of the prosperous rice. This is due to several obstacles that often occur in the prosperous rice program, which are due to inaccurate data, where the criteria for measuring poverty levels used by BPS today cannot anymore identify the community as poor or not, so there are still many benefit households whose names not recorded in the list of beneficiaries of prosperous rice.

\section{Right Quality}

The quality of rice does in accordance with the general guidelines of Rastra. As happened in Muara Wis, precisely in Lebak Village, the former rice was ugly, yellowish, cracked and sometimes lice found. Whereas in the guidelines it is stated that the quality of rice must be in accordance with the requirements as stipulated in the applicable regulations, namely rice in good condition. This is due to the accumulation of rice in the bulog warehouse, which is caused by the unavailability of distribution funds that go down every month.

\section{Exact Amount}

The amount sent to all RTSPM in the Muara Wis has met the established standards of $15 \mathrm{~kg}$ per family, which means that there is no significant saving in terms of the amount of rice for the poor. 


\section{Timely}

Based on the results of the comparison, it can be seen that Raskin suppliers are not on time in sending based on interviews with several communities in seven villages as well as government apparatus related to supervision, namely that raskin delivery time should be done once a month but that occurs more than that sometimes three months even up to six months, this happens because of constraints in access to raskin delivery, so that timely indicators are difficult for Raskin poets to run.

\section{Right Price}

In terms of price accuracy in the implementation of distribution of prosperous rice, it is not in accordance with the guidelines. The price of tebus rastra according to the technical manual for the implementation of Rastra from the target beneficiary household to the implementers of the rastra distribution is done in cash, amounting to 1,600 / $\mathrm{kg}$ at the distribution point. However, with limited subsidies on postage, the recipient of the assistance for the prosperous rice adds shipping costs of Rp. 500 / kg. The additional IDR 500 / kg is used as an additional fee in exchange for transport and operational money in the field.

\section{Proper Administration}

In implementing Raskin distribution the government has implemented administrative order that can be seen from the fulfillment of administrative requirements in a complete and timely manner. Based on the results of the comparative system in the repressive supervision model, it can be seen that based on the 6 indicators of success, one of them is still more or less precisely, namely the right quality and the wrong target, while the other four indicators can be run well, although there are few indicators but they can completed, as reported by one of the people from RT 2 Dusun Tanah Harapan Desa Lebak Mantan that the delivery of rice run by his RT had been channeled to residents who deserved it, namely the RTSPM that had previously been recorded.

\section{Corrective Actions in the Rastra Distribution Supervision in the Kutai Kartanegara District Government in Muara Wis}

The performance of Raskin distribution with the prescribed standards is seen when supervisors can implement corrective actions/evaluations of the Raskin distribution team's work, as stated by T Hani Handoko (1984) that corrective actions need to be taken by the manager if the results of analysis or interpretation the supervisor sees a deviation or error in performing the performance so that it is not in accordance with the predetermined plan, Handoko further suggested that in the corrective action it could be standard changes, changes in measurement of supervision, or can change the way of analyzing performance with standards. But what happened to the corrective action that should have been there as a form of supervision results has not been implemented well, because in the following year the same mistakes still occur, can be seen based on the results of the analysis that the government needs to improve the data by re-registering RTSPM because it has been explained before that the data held by BPS can no longer be used as a guideline in determining the number of mandatory RTSPM in Muara Wis, furthermore that Geographical factors as well as infrastructure become an obstacle to the supervisory process so that improvements can be made in determining supervision measurements, in this case the government can establish or add a team in supervision, meaning that the availability of human resources needs to be considered considering the number of supervisory teams is only two, based on the conditions needed to re-add the team, and the most important is that development of infrastructure both roads and telecommunications so that the supervision of remote areas can be covered by the supervisor team, the latter which deals with the problems of the quality of rice delivered by bulog where 
the local government, especially Kutai Kartanegara District Local Government, needs to evaluate the performance of bulog. ${ }^{3}$

\section{CONCLUSION}

The rice subsidy program for low-income people (the Rastra Program) is a cross-sectoral national program that aims to help meet the rice needs of low-income people. As a national program, this program involves various parties, both vertical and horizontal. Horizontally all related sectors have responsibilities and authorities in accordance with their respective main tasks and functions: planning and Provision of subsidized budgets, determination of RTS and ceiling of Rastra, handling public complaints, supervising and controlling programs and coordinating. To achieve this goal, it is necessary to supervise prosperous rice so that the goal of distributing prosperous rice can be achieved.

\section{References}

Adam, I. 2000. Perilaku Organisasi. Bandung: Sinar Baru Algesindo.

Creswell, Jhon. 2016. Research Design: Pendekatan Metode Kualitatif, Kuantitatif dan Campuran. Yogyakarta : Pustaka Pelajar.

Handayaningrat, Soewarno. 1980. Pengantar Studi Ilmu Administrasi dan Manajemen. Jakarta: CV. Haji Masagung.

Handoko, T Hani. 1984. Manajemen. Yogyakarta : BPFE.

Hasibuan, Malayu S.P. 2001. Manajemen (Dasar, Pengertian, Dan Masalah). Bandung: PT. Bumi Aksara.

Koontz, H. a. 1959. Principles Of Management. Tokyo Japan: PT Gramedia Pustaka Utama.

Kaho, J.R. 1995. Prospek Otonomi Daerah Di Negara Republik Indonesia. Jakarta: PT Raja Grafindo Persada.

Sarundjangan, H. S. 2006. Babak Baru Sistem Pemerintahan Daerah. Jakarta: Kata Hasta Pustaka.

Soewartojo. 1995. Manajemen. Jakarta: Ghalia Indonesia.

Siswanto, H.B. 2005. Pengantar Manajemen. Bandung: PT Bumi Aksara.

Terry, G. 1960. Principle Of Management (Third Edition). Richard D. Irwin inc: Homewood.

Siagian, P.S. 1995. Filsafat Administrasi. Jakarta: Gunung Agung.

Winarno, B. 2011. Isu-Isu Global Kontemporer. Yogyakarta: CAPS

3 jokowi-ingatkan-mensos-beras-raskin-yang-hitam-dan-berkutu dari : https://www.jpnn.com/news (accessed in 18 January 2017, 15.00 PM) 